\title{
Early Palaeocene Parvularugoglobigerina and late Eocene Praetenuitella: does evolutionary convergence imply similar habitat?
}

\author{
QIANYU LI' ${ }^{\prime}$, B. McGOWRAN' \& A. BOERSMA ${ }^{2}$ \\ 'Department of Geology and Geophysics, The University of Adelaide, Adelaide, S. A. 5005, Australia. \\ ${ }^{2}$ Microclimates, 540 Gate Hill Road, Stony Point, NY 10980, USA.
}

\begin{abstract}
The species of the earliest Palaeocene planktonic foraminiferal genus Parvularugoglobigerina are characterized by a small test with a smooth, microperforate wall and an clongate aperture. Pore-mound structures may occur on some specimens, while the coiling mode varies from high- to low-trochospiral. Four morphotypes are distinct enough to be recognized as species: $P$. eugubina (Luterbacher \& Premoli Silva) is low spiral and multichambered and $P$. perexigua $n$. sp. is four-chambered; $P$. fodina (Blow) has a Globigerina bulloides-type morphology and $P$. alticonusa $\mathrm{n}$. sp. has a high trochospire. With the exception of the high spire, this general morphology is repeated in late Eocene forms classified as Praetenuitella: $P$. insolita (Jenkins), P. patefacta Li, and other associated forms.

The two groups acquired their strong similarities - highly distinctive, peculiarly elongated aperture and microperforate walls - through evolutionary convergence. not by being directly related. Stratigraphically they each have a brief occurrence in a geologically significant slice of Palaeogene time: the one during the recovery of ecosystems in the earliest Palaeocene; the other immediately prior to the great cooling and in the time of rapid change known as the Terminal Eocene Event. This study shows that Praetenuitella flourished in eutrophic conditions and that their evolution might have been nutrient-driven. We suggest by morphological pattern analogy that forms of Praetenuitella and Parvulorugoglobigerina reflect similar habitat in their similar form and especially in their aperture. $J$. Micropalaeontol. 14(2): 119-134, October 1995.
\end{abstract}

\section{INTRODUCTION}

Hofker (1978) introduced the generic name Parvularugoglobigerina to include forms described as and related to Globigerina eugubina Luterbacher \& Premoli Silva (1964), occurring immediately above the Cretaceous/Palaeogene $(\mathrm{K} / \mathrm{P})$ boundary. Using schematic drawings, Hofker referred forms with heavy pustules to the type species eugubina. Smit (1982), however, showed that eugubina is smooth and finely (rather than heavily) pustulate and microperforate, although the micropores are scattered and difficult to observe. Globorotalia (Turborotalia) longiapertura Blow (1979) falls within Smit's (1982) species concept for Globigerina eugubina; accordingly, we treat longiaperta as a junior synonym of eugubina. This view has been followed by several others including Boersma \& Premoli Silva (1983), Toumarkine \& Luterbacher (1985), Brinkhuis \& Zachariasse (1988) and Keller (1988), but Canudo et al. (1991) considered longiapertura as a distinct species. Specimens of $P$. eugubina from the Millers Ferry section in Alabama have recently been found to possess pore-mounds on the wall surface (Olsson et al., 1992), whereas most individuals are smooth with scattered micropores. Wall texture aside, the most conspicuous character of $P$. eugubina is the highly elongate aperture. Praetenuitella spp. from the late Eocene also possess an elongate aperture. Beginning with a comparison of the two groups, this study considers the implications of the strongly convergent development of the aperture, which is most unusual among the Cenozoic planktonic foraminifera in its form. Material from DSDP Holes 152 and 577, ODP Hole $749 \mathrm{~B}$ and the Otway Basin in southern Australia was examined and some typical specimens of selected species are illustrated.

\section{MORPHOLOGICAL CHARATERISTICS OF PARVULARUGOGLOBIGERINA}

1. Test and coiling

The test in most species of Parvularugoglobigerina has 8-12 subglobular to globular chambers, with $4-7$ in the final whorl. Chambers increase slowly in the inner whorl but rapidly in the outer, final whorl. The test diameter ranges commonly from 80-150 $\mu \mathrm{m}$ (Pl. 1), although tests as large as $220 \mu \mathrm{m}$ have been found (Olsson, 1992, pers. comm.). Coiling is dominantly low trochospiral, as seen in the type species, P. eugubina (Pl. 1, figs 1-11), but intermediates are common between the low- and high-trochospiral forms (Pl. 2 , figs 8,9 ).

\section{Surface texture}

The wall is smooth but may be slightly rugose due to the overgrowth of calcite particles on many specimens in our material. Unlike the true pustules, these calcite particles, or pseudopustules, are closely packed (see also Hemleben et al., 1991: Olsson et al., 1992). This can be easily observed when specimens have been poorly preserved or slightly dissolved (Pl. 1, fig. 7; Pl. 2, fig. 3). On the other hand, forms with typical pore-mounds ( $\mathrm{Pl}$. 1, figs. 3-7) have similar, but less distinct, characters to those on the triserial Guembelitria cretacea Cushman. This has led Olsson et al. (1992) to propose their affinity, i.e. the parvularugoglobigerines may be the direct descendants of $G$. cretacea. This can be disputed because the pore-mound structure has been 
observed independently on several forms which are phylogenetically unrelated: the early Cretaceous Blefuscuiana (see illustrations in Banner \& Desai, 1988; Banner et al., 1993), the late Cretaceous to early Palaeocene G. cretacea and Oligocene-Miocene Cassigerinella chipolensis s.l. Banner \& Desai (1988) suggested that the origin of $P$. eugubina could be descended directly from late Cretaceous Blefuscuiana with minimal morphological change.

The perforations on $P$. eugubina, when observable, are extremely small, about $0.2-0.3 \mu \mathrm{m}$ in diameter, and irregularly distributed (Pl. 1, figs 2, 3, 6, 7). With about 5 micropores per $100 \mu \mathrm{m}^{2}$, pore density of P. eugubina is the lowest among the Cenozoic microperforate planktonic taxa, as is the porosity which is only $2 \%$ or less $(\mathrm{Li}, 1991)$.

\section{Apertural features}

As observed earlier by Blow (1979) on Globorotalia (Turborotalia) longiapertura $(=P$. eugubina), the aperture in most tests is high and elongate. In low trochospiral individuals (typical of longiapertura) the aperture is (umbilical-) extraumbilical and extends onto the apertural face (Pl. 1, figs 1, 2, 4-6, 8-10). It gradually moves towards the umbilicus when the test becomes high trochospiral (Pl. 2, figs 6-10). The apertural lip is absent from some specimens of $P$. eugubina ( $\mathrm{Pl}$. 1, figs $4-6,10$ ), but may be well developed in some others (Pl. 1, figs 1, 2, 8, 9). As reported by Gerstel et al. (1986) and D'Hondt \& Keller (1991) and observed by us in DSDP Holes 465 and 577, many specimens of $P$. eugubina have aberrant and varying apertures, which may extend onto the spiral (dorsal) side.

\section{MORPHOTYPES OF \\ PARVULARUGOGLOBIGERINA}

Four morphotypes here grouped within the genus Parvularugoglobigerina are considered to warrant taxonomic distinction. They are $P$. eugubina (Luterbacher \& Premoli Silva), $P$. fodina (Blow), $P$. perexigua n. sp. and $P$. alticonusa $\mathrm{n}$. sp. Specimens of the eugubina-type and perexigua-type are both characterized by a low trochospire, but they can be separated by 5 or more and only 4 chambers in the final whorl respectively. By contrast, $P$. fodina possesses a medium-high spire and an almost circular aperture, while $P$. alticonusa is high and has an elongate aperture similar to that of typical eugubina. Detailed taxonomic discussions on these and several related taxa are presented in Appendix A.

\section{EVOLUTION AND DISTRIBUTION OF PARVULARUGOGLOBIGERINA}

Parvularugoglobigerina is now known to be a microperforate genus having various morphotypes. Changes in the spire height from high to low or vice versa, accompanied by changes in the apertural location, are useful for differentiation of species (or morphotypes). Some morphotypes have been misidentified; those, for example, with four-chambered tests described by Brinkhuis \& Zachariasse (1988) among others, as Globigerina fringa Subbotina should be the new species $P$. perexigua, because the types of $G$. fringa possess a cancellate wall and belong therefore in the eoglobigerines (Berggren, 1990, pers. comm.; Berggren, 1992). Similarly, the records of $P$. minutula from various K/P boundary sections (e.g. Smit, 1982; as $G$. conusa, 1989 in Keller, 1988) should be changed to P. alticonusa, for Globigerina minutula Luterbacher and Premoli Silva is in fact an early subbotinid with a distinct cancellate wall (Premoli Silva, 1990, pers. comm.), although the type material has recently been found to be so heavily recrystallized 'that the wall texture was completely uninterpretable' (Olsson, 1992, pers. comm.). From our present knowledge of this group, however, it became diverse shortly after the K/P boundary mass extinction (Premoli Silva, 1977; Boersma \& Premoli Silva, 1991). Figure 1 shows the approximate ranges of Parvularugoglobigerina spp. and other genera in the early Palaeocene.

From the K/P boundary section at El Kef in NW Tunisia, Brinkhuis \& Zachariasse (1988) suggested that both Globoconusa minutula $(=P$. alticonusa $)$ and $P$. fringa $(=P$. perexigua) probably evolved from a benthic form Caucasina, simply by increasing chamber volumes to achieve buoyancy. This suggestion may confirm Hofker's (1978) view that Parvularugoglobigerina might have arisen from the larval stage of a benthic form. But alternative explanations are equally tenable. For example, Banner \& Desai (1988) concluded that the Cretaceous Blefuscuiana was its likely ancestor, while we obeserved a complete transitional series between the triserial-biseral planktonic GuembelitriaWoodringina and Parvularugoglobigerina spp. from DSDP Hole 465A. On the other hand, Olsson et al. (1992) derived both Parvularugoglobigerina and Globoconusa from Guembelitria, on the evidence that early representatives of these genera are all similar to Gumbelitria in having a microperforate and mounded wall, although diagenetic calcite growth may alter this wall surface texture. Also like Guembelitria, many forms of Parvularugoglobigerina (referable to $P$. alticonusa) are high trochospired. From the El Kef section, Brinkhuis \& Zachariasse (1988), Keller (1988) and D'Hondt \& Keller (1991) reported that forms of the alticonusa-type $(=P$. minutula, or $P$. morphotype 1 of these authors) occurred together with the compressed $P$. eugubina. If Gumbelitria is the ancestral form, then the immediate descendant to mark the establishment of the genus Parvularugoglobigerina must be $P$. alticonusa, from

\section{Explanation of Plate 1}

Parvularugoglobigerina eugubina (Luterbacher \& Premoli Silva) from the basal Palaeocene (Zone P $\alpha$ ). Scale bar $=50 \mu \mathrm{m}$ unless indicated otherwise. Fig. 1. Specimen from Sample $577-12-5,113-114 \mathrm{~cm}$. Figs 2, 3. Specimen from Sample 152-10-1, 140-143 cm. Note the pore-mound texture. Figs 4, 5. Single specimen with a lipless aperture form Sample 152-10-1, 140-143 cm. Figs 6-8. Specimens from Sample 152-10-1, 140-143 cm. Note the pseudopustules and scattered micropores with less distinct pore-mounds. Fig. 9. Specimen with a well developed apertural lip from Sample 577-12-5, 113-114 cm. Figs 10, 11. Two specimens with a low trochospire from Sample 152-10-1, 140-143 cm. 

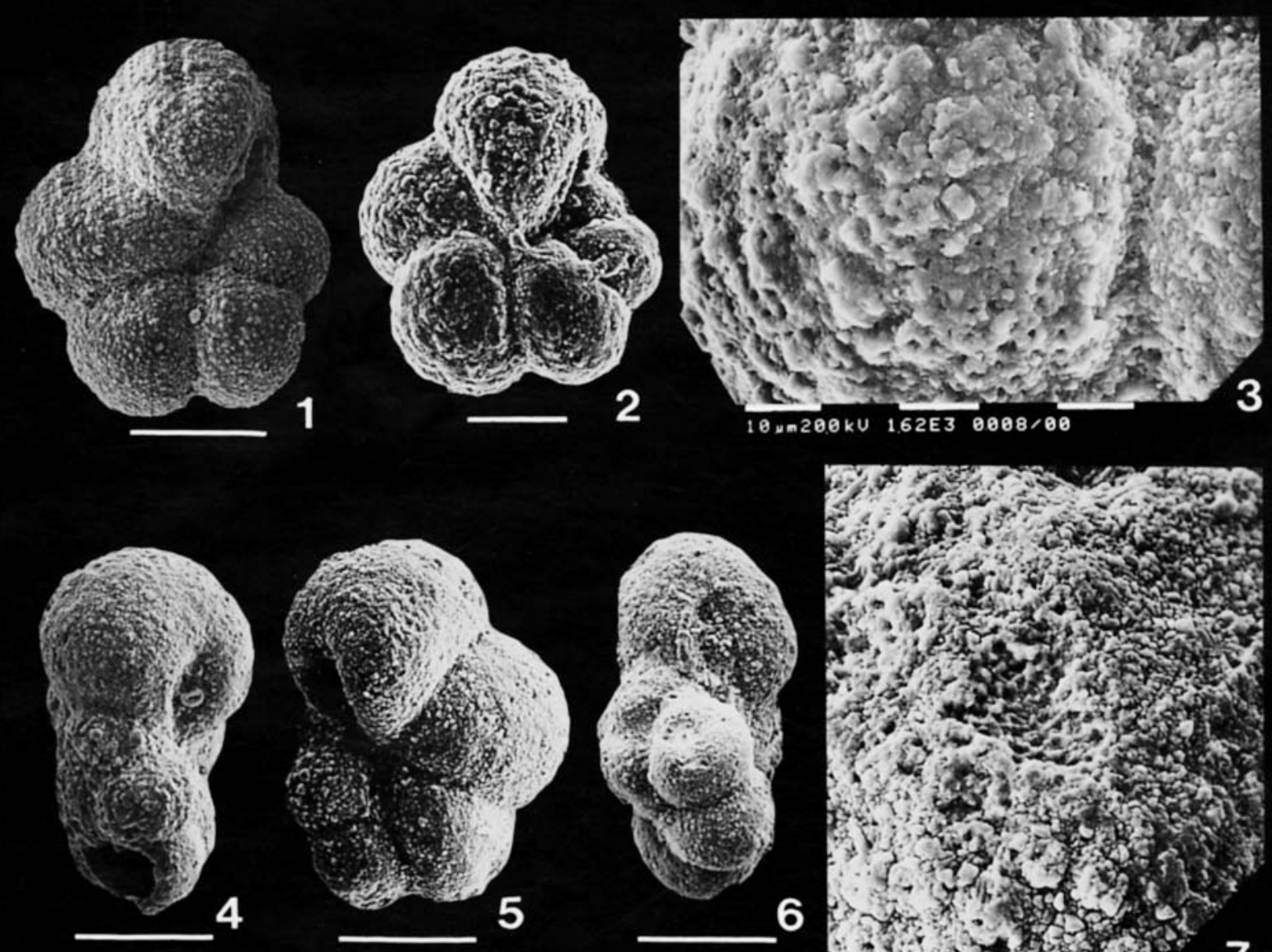

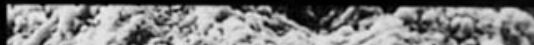

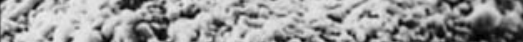

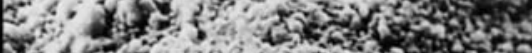

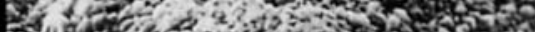

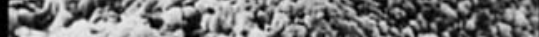

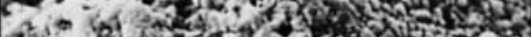

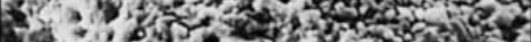

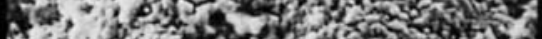

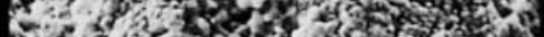

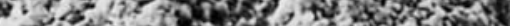

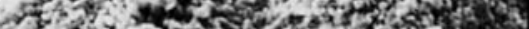

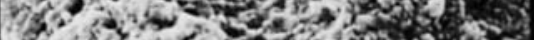
C N

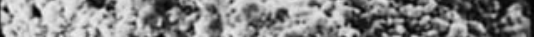

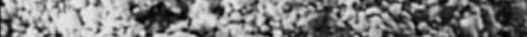

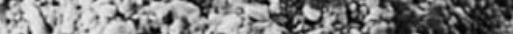

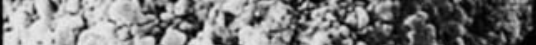

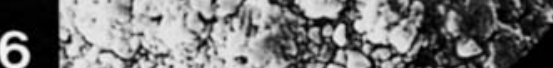

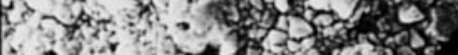

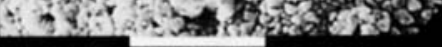
$10 \mathrm{~mm} 20.0 \mathrm{kV}$
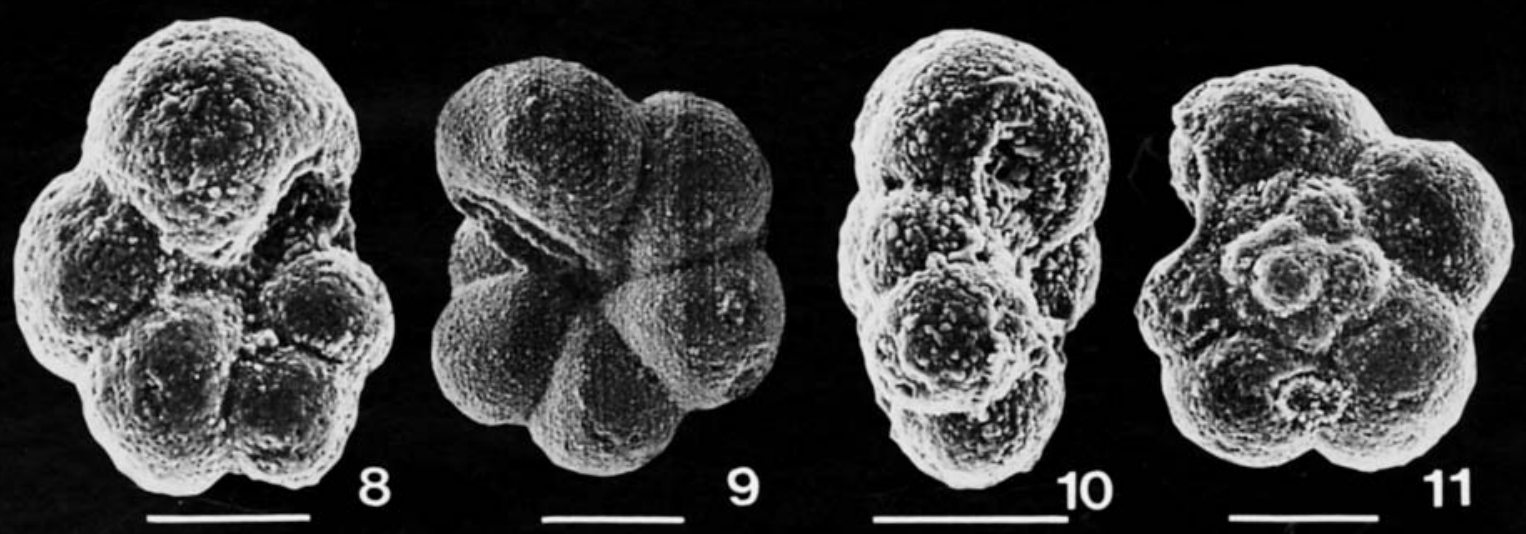

Plate 1 

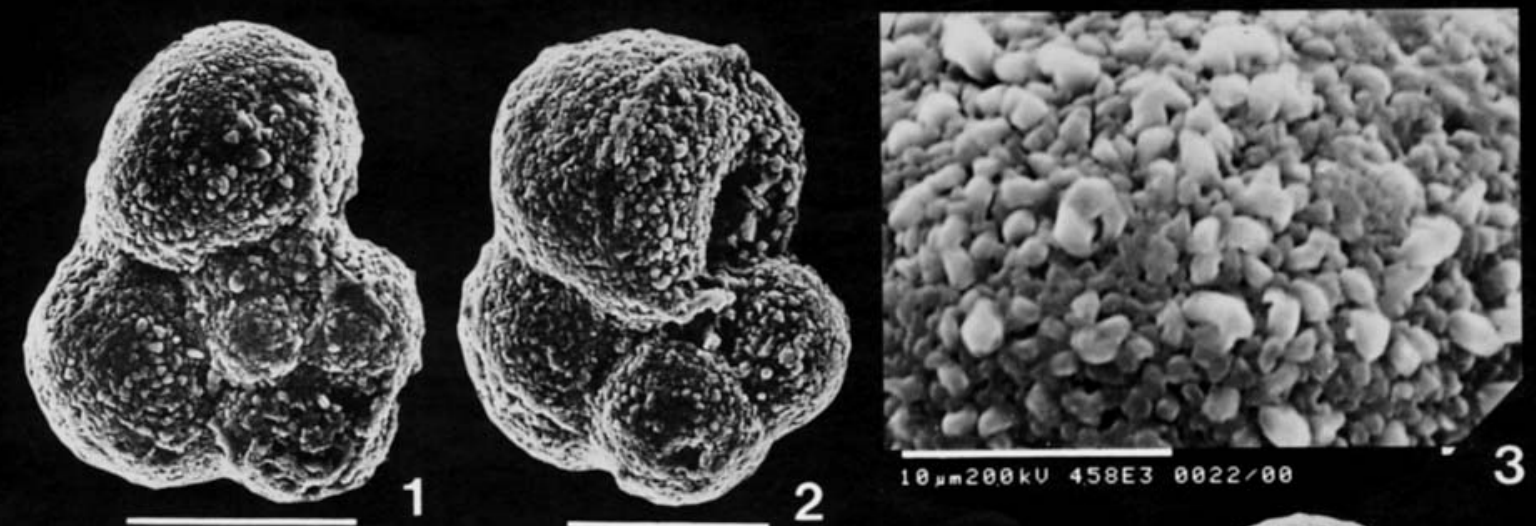

3
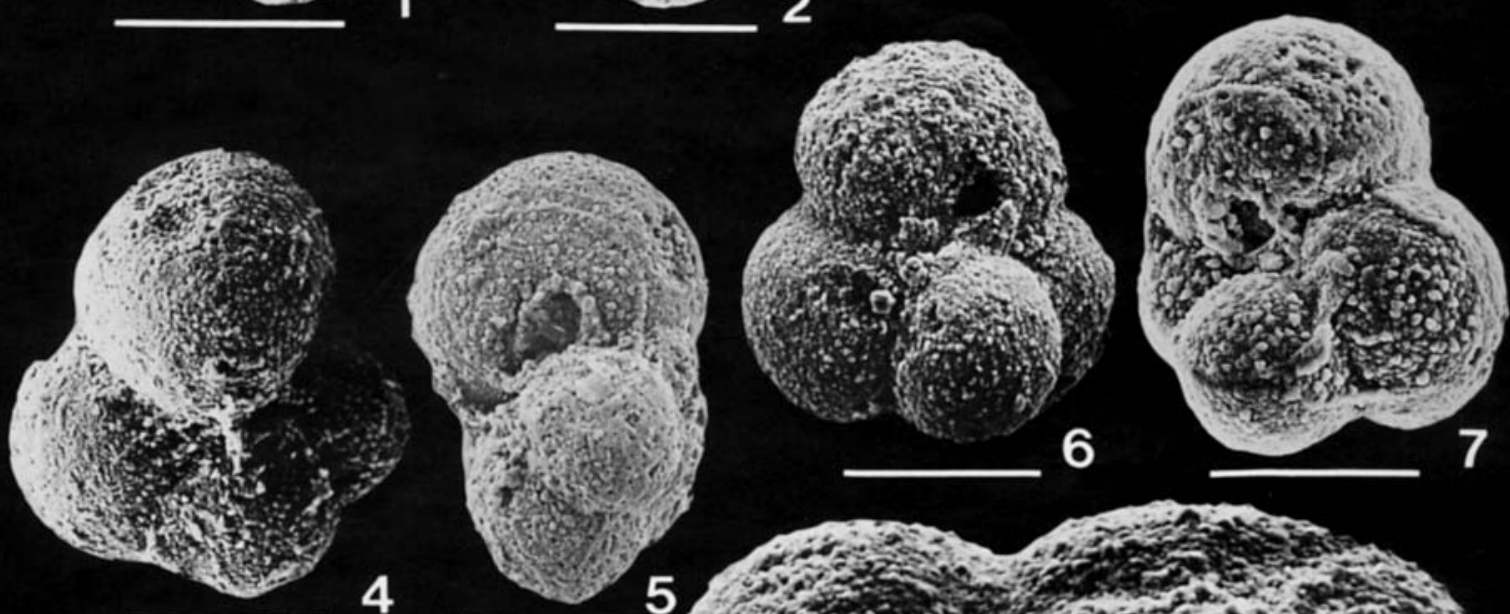

6
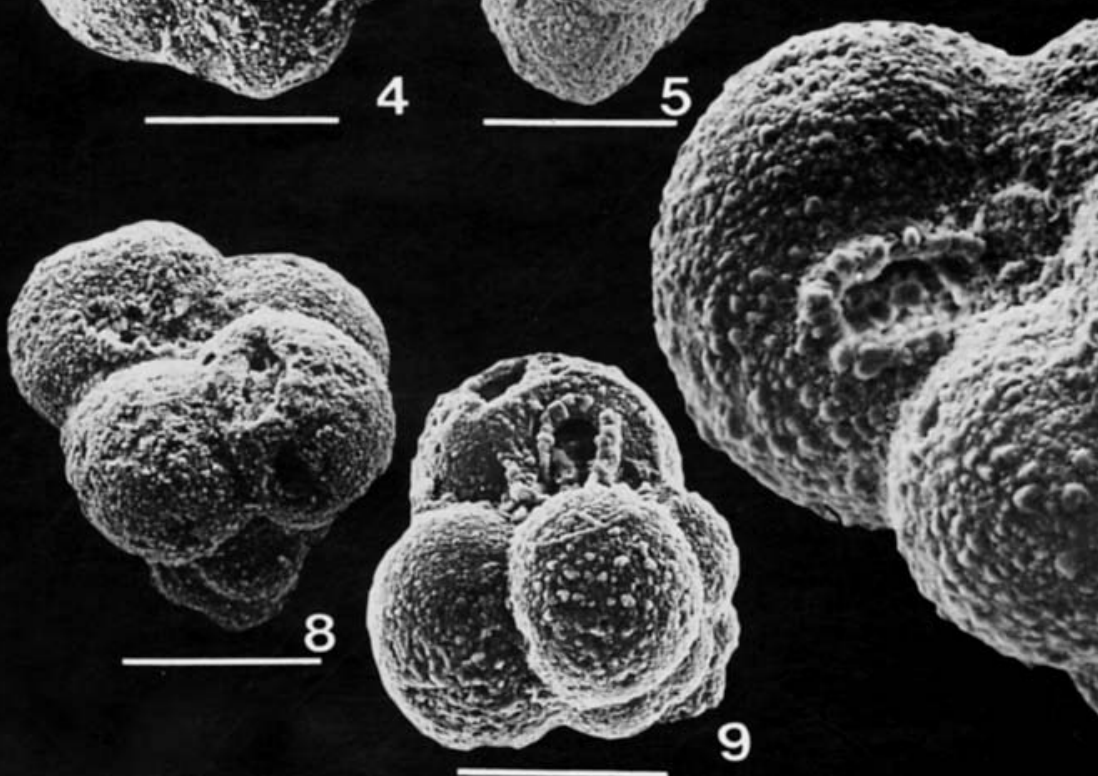

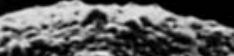

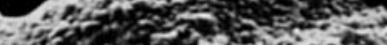

5

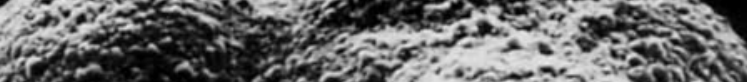
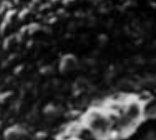

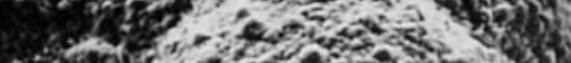

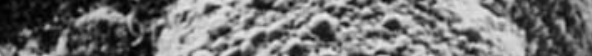

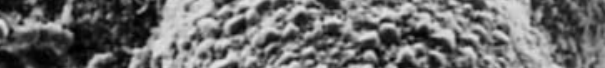




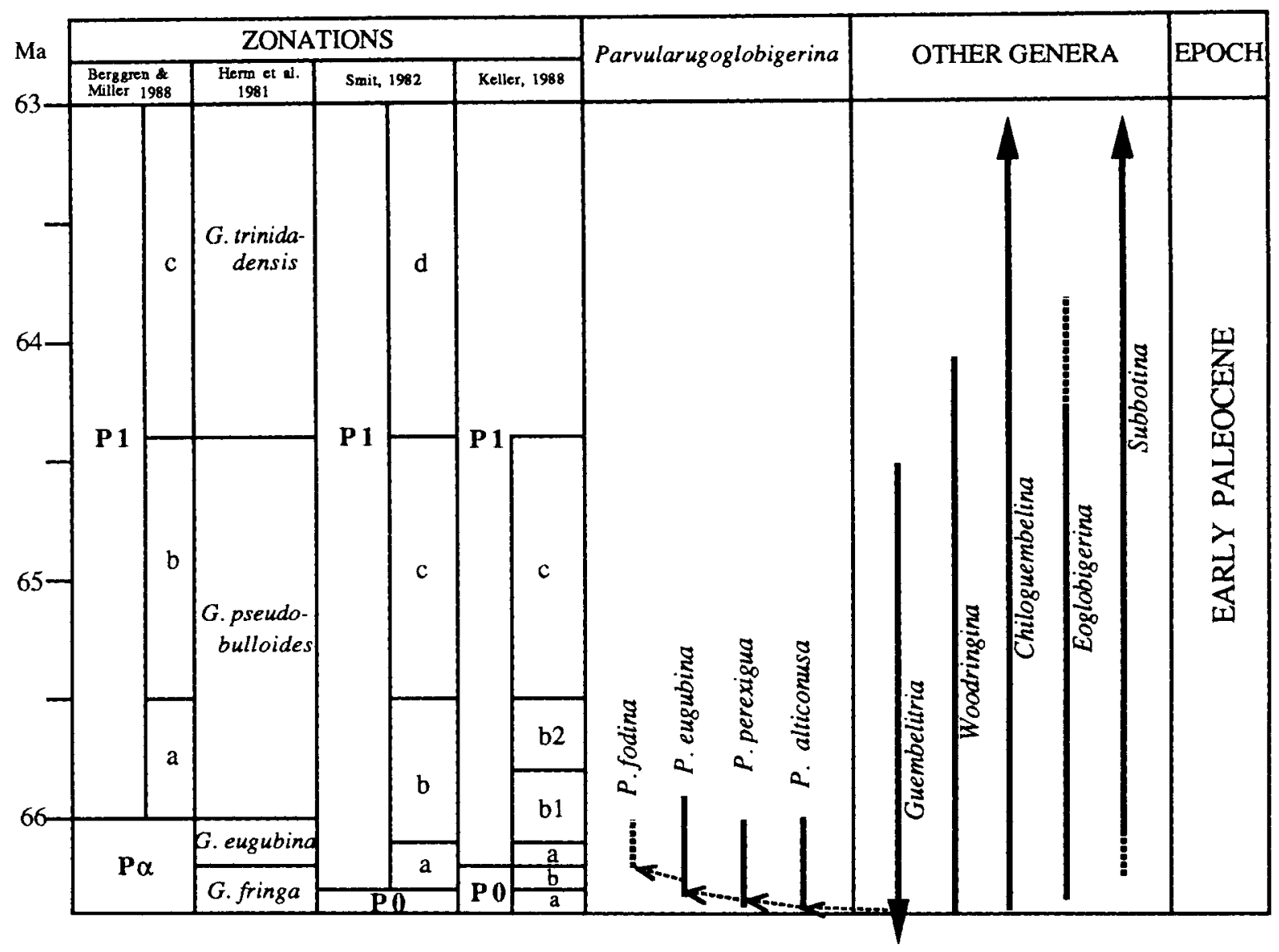

Fig. 1. Ranges of Parvularugoglobigerina spp. and related genera in the early Palaeocene. Chronology from Berggren et al. (1985). Several planktonic foraminiferal zonations are shown.

which all other parvularugoglobigerine morphotypes evolved in succession. We therefore suggest the evolutionary bioseries to be likely from $P$. alticonusa to perexigua (and fodina) to eugubina, where $P$. fodina may only represent a short branching from the main stock (Fig. 1). After a short period of proliferation, all species of Parvularugoglobigerina became extinct within Zone $\mathrm{P} 1$, leaving no direct descendants. (In contrast, Blow (1979) and Banner (1989) suggested that this lineage might lead to the appearance of several early Palaeocene groups, including Globanomalina.)

Species of Parvularugoglobigerina occur immediately above the $K / P$ boundary in the earliest Palaeocene and indicate an age older than $65 \mathrm{Ma}$ in the early part of Zone $\mathrm{P} \alpha$ of Blow (1979) (Berggren et al., 1985), a level now recognized as Zone P0 (Smit, 1982; Olsson et al., 1992). A recent discovery by Montgomery et al. (1992) that a clastic event bed at the Brazos River $\mathrm{K} / \mathrm{P}$ boundary section previously attributed to the latest Cretaceous is in fact the earliest Palaeocene. The presence of several Cretaceous species in that layer is due to reworking which had occurred several times during earliest Palaeocene time.

A reconstruction of the spatial distribution of $P$. eugubina (Fig. 2) shows that this species is widely distributed, with high abundances inferred in upwelling regions during the earliest Palaeocene. It may reach $50 \%$ in samples from the eugubina zone from many localities, including Spain (Smit, 1982), Denmark (Boersma \& Premoli Silva, 1983, 1991), Shatsky Rise (Gerstel et al., 1986) and Tunisia (Keller, 1988). In polar areas it is rare or absent, and the planktonic foraminiferal fauna there is dominated by fringa-type, macroperforate forms (Stott \& Kennett, 1990, Weddell Sea, Antarctica; Berggren, 1992, Kerguelen Plateau).

\section{Explanation of Plate 2}

Parvularugoglobigerina spp. from the basal Palaeocene (Zone $P \alpha$ ). Scale bar $=50 \mu \mathrm{m}$ unless indicated otherwise. Figs 1-5. Parvularugoglobigerina perexigua n. sp. from Sample 152-10-1, 140-143 cm; figs 1-3, holotype, with fig. 3 enlarged to show pseudopustules due to dissolution; figs 4 and 5 are two views of paratype. Figs 6, 7. Parvularugoglobigerina fodina (Blow). Two specimens with a semicircular, axiointraumbilical aperture from Sample 152-10-1, 140-143 cm Figs 8-10. Paroularugoglobigerina alticonusa n. sp., with a high trochospiral coiling from Sample 152-10-1, 140-143 cm (fig. 8, paratype; fig. 9, holotype) and Sample 577-12-5, 113-114 cm (fig. 10, paratype). 


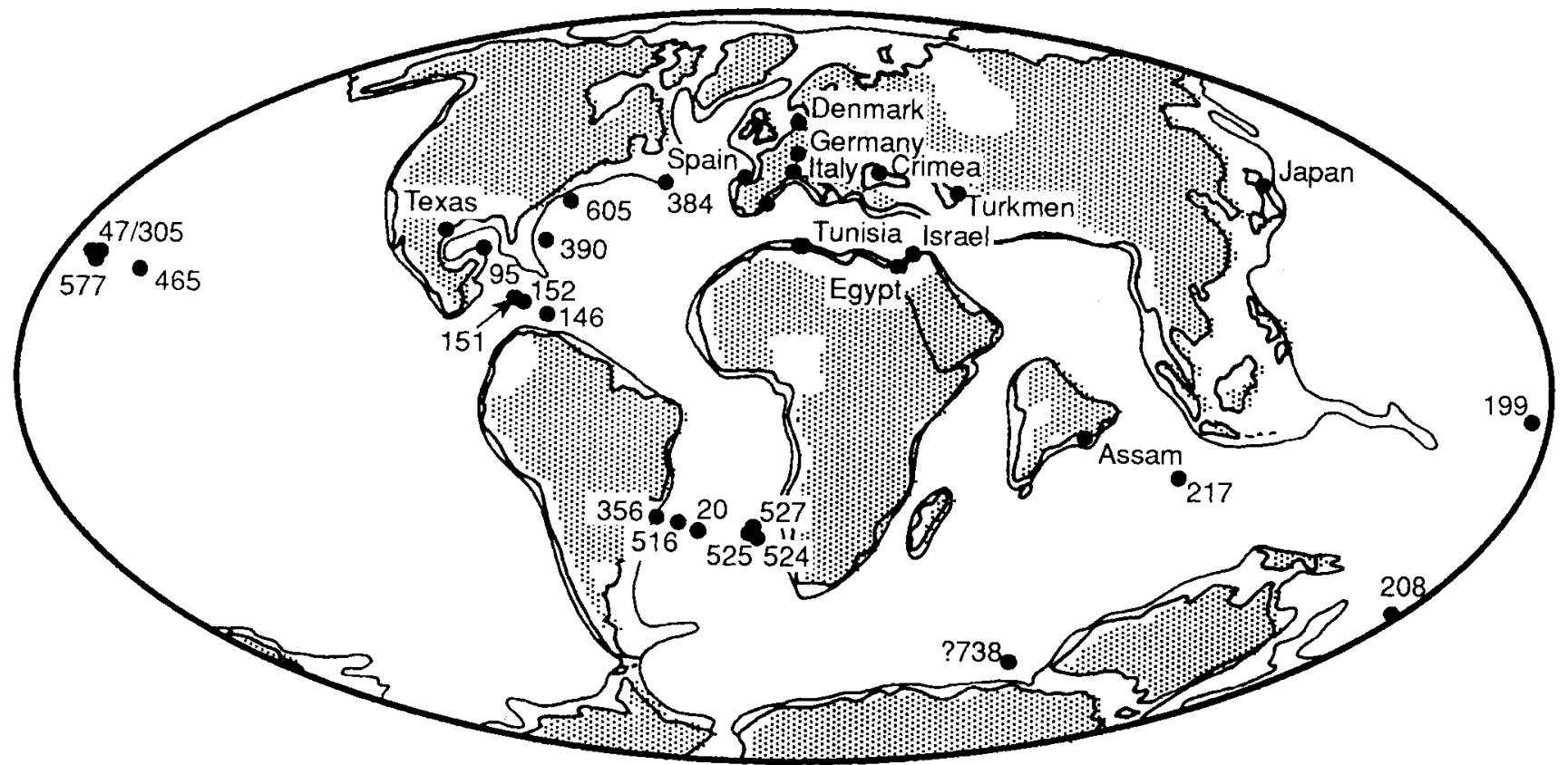

Fig. 2. Distribution of Parvularugoglobigerina eugubina in the earliest Palaeocene, as modified from Li \& Radford (1991), on a base map adapted from Haq \& Van Eysinga (1987) for the middle Palaeocene, at $60 \mathrm{Ma}$.

Another species commonly encountered is $P$. alticonusa. Smit (1982) and Brinkhuis \& Zachariasse (1988) demonstrated that this species (as $G$. conusa) is the second most common microperforate species in Palaeocene sections in Spain and Tunisia. It was also recorded in this study from DSDP Hole 152 in the Caribbean and DSDP Hole 577 on Shatsky Rise. On the other hand, the geographic distributions of both $P$. fodina and $P$. fringa are poorly known, although the former was found in its type locality in DSDP Hole 47.2 on Shatsky Rise by Blow (1979) and in Hole 152 in this study.

\section{THE LATE EOCENE PRAETENUITELLA, AN ANALOGUE OF PARVULARUGOGLOBIGERINA?}

The genus Praetenuitella, erected by Li (1987) and discussed further by $\mathrm{Li}$ et al. (1992), includes the late Eocene tenuitellids with a small maximum test size (about $150 \mu \mathrm{m}$ ) characterized by a smooth, microperforate wall and by an elongate aperture (PIs 3 and 4). Represented by $P$. insolita (Pl. 3, figs 1-12; Pl. 4, figs 7-9) and P. patefacta (Pl. 4, figs
1-4), Praetenuitella is believed to have originated from Pseudohastigerina and subsequently given rise to Tenuitella spp. close to the Eocene/Oligocene boundary. Uncertainty remains because Pseudohastigerina is planispiral and smooth-walled, whereas Tenuitella is trochospiral and pustulate-walled. Although the trochospiral coiling is constantly low, Praetenuitella mimics the apertural character of Parvularugoglobigerina and these two taxa, as shown in Plates $1-4$, are extremely similar in overall test morphology, thus representing one of the strongest convergent developments among Cenozoic planktonic foraminifera. The late Eocene Praetenuitella is a homeomorph of, but phylogenetically unrelated to, the early Palaeocene Parvularugoglobigerina. Unlike the parvularugoglobigerines, Praetenuitella had issue, giving rise to Tenuitella close to the Eocene-Oligocene boundary in an evolutionary transformation recorded in many localities ( $\mathrm{Li}, 1991)$. Brief notes on Praetenuitella species are given in Appendix B.

Praetenuitella insolita was described from a short interval in the Port Elizabeth section in New Zealand, where it extends from just below the highest Acarinina collactea

\section{Explanation of Plate 3}

Praetenuitella spp. from the late Eocene of the Browns Creek Formation, Otway Basin, southern Australia (see McGowran et al., 1992 for discussions on stratigraphy and palaeoenvironment). Scale bar $=50 \mu \mathrm{m}$. Figs 1-7, 9, 10. Praetenuitella insolita (Jenkins). This species is characterized by 4-5 oval chambers in the final whorl, a smooth wall surface and a rather convex dorsal (spiral) side. Fig. 8. Intermediate form between $P$. insolita and $P$. patefacta (see Pl. 4). Figs 11, 12. Intermediate specimens between $P$. insolita and $P$. praegemma (see Pl. 4) with more than 5 chambers in the final whorl. 

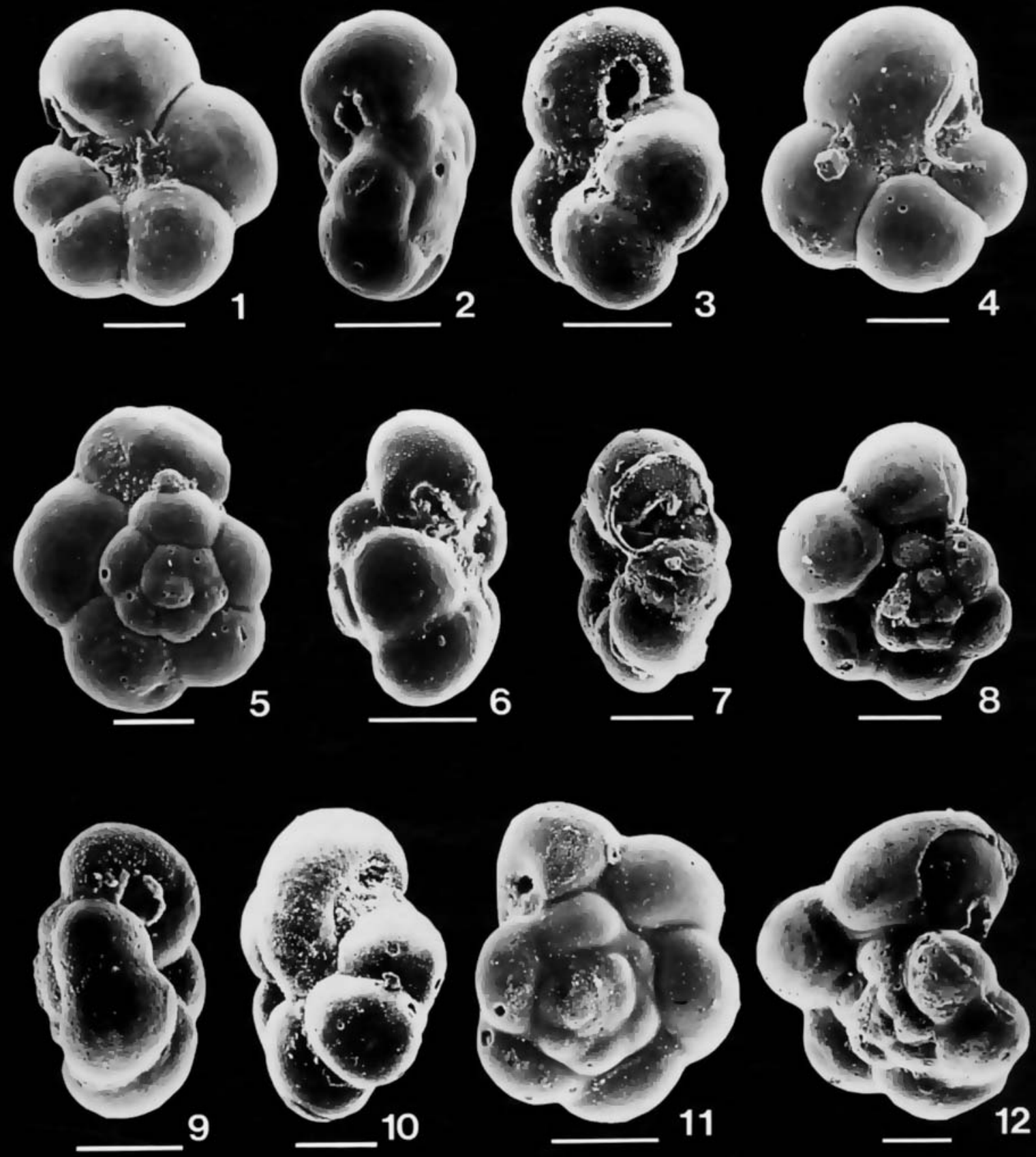

Plate 3 


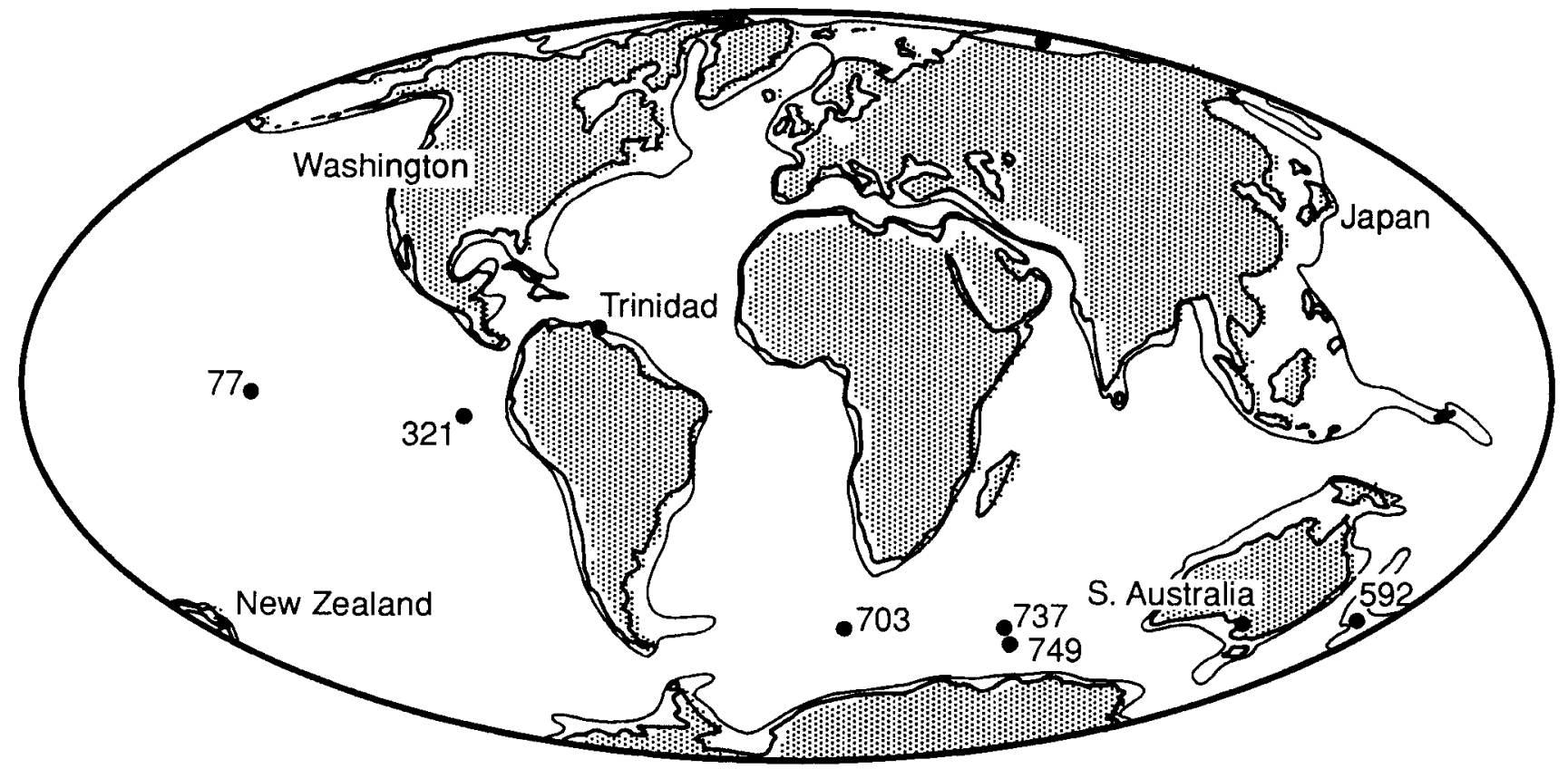

Fig. 3. Distribution of Praetenuitella insolita in the late Eocene on a base map adapted from Haq \& Van Eysinga (1987) for the middle Oligocene at $30 \mathrm{Ma}$. Data sources are cited in the text.

(Finlay) to just below the highest Globigerinatheka spp. (Jenkins, 1966). The composite range in southern Australia is very similar or even identical, extending as it does from one recorded co-occurrence with Acarinina primitiva (Finlay) at the base (correlated approximately with the P14/P15 boundary), to the topmost records which are with the last Globigerinatheka (McGowran, 1991). The brief range of $P$. insolita coupled with their sometimes high frequency encouraged the establishment and recognition of a $P$. insolita zone (= Globorotalia insolita zone of Jenkins \& Orr, 1972) in the southern hemisphere (Nocchi et al., 1991; Li et al., 1992). The zone is distinctive and easily recognized particularly at high southern latitudes, as at ODP Hole 749B on the Kerguelen Plateau (Fig. 4). Kaiho (1984) found similar forms in Japan but most records are from the southern hemisphere (Fig. 3; see also Quilty, 1976; Jenkins \& Srinivasan, 1985).

The occurrence of $P$. insolita in neritic sediments in southern Australia gives us some insight into the species' preferences. Figure 5 shows the relative abundances of 'Tenuitella gemma/munda/insolita' (which is mostly $P$. insolita in the late Eocene). Visual inspection shows a distinct tendency to associate with Chiloguembelina cubensis and Pseudohastigeria micra. This group of species collectively is high in its relative abundance when Globigerinatheka is low and vice versa. That suggests fluctuations in nutrient, Globigerinatheka being the more oligotrophic. But the Blanche Point Formation as a whole is grey-green to black with high carbon content and very rich in opaline silica, and its benthic foraminiferal faunas are rich in uvigerinids and bolivinids (McGowran \& Beecroft, 1986). The combined foraminiferal (benthic and planktonic), organic geochemical, macrofossil and sedimentary evidence suggests a brief time of high productivity on the southern Australian margin in both open and restricted environments. That brief time essentially is confined to third-order cycles 4.2-(lowermost) 4.3 or, approximately, to planktonic foraminiferal zones upper P15-P16 (Fig. 6).

\section{Explanation of Plate 4}

Praetenuitella spp. from the late Eocene in ODP Hole 749B, southern Indian Ocean. Scale bar $=50 \mu \mathrm{m}$ unless indicated otherwise. Figs 1-4. Praetenuitella patefacta $\mathrm{Li}$ from Sample 749B-3-1, 36-38 cm having an almost planispiral test (figs 1 and 2 are different views of a single specimen). Figs 5, 6. Intermediate specimens between $P$. patefacta and $P$. insolita, from Sample 749B-3-1, 36-38 cm, showing the oval, rather than spherical, chambers and an aperture migrating away from the pheriphery. Figs 7-9. Two specimens of $P$. insolita with a slightly convex dorsal side from Sample 749B-3-1, 36-38 cm. Also note that the microperforate wall on fig. 9, enlarged from fig. 8, has been obscured by diagenesis. Figs 10, 11. Praetenuitella praegemma Li, two specimens from Samples 749B-3-1, 36-38 cm and 749B-3-2, 50-53 cm respectively, with an umbilical-extraumbilical aperture. Fig. 12. Part of the population of Praetenuitella spp. from Sample 749B-3-1, 36-38 cm. 

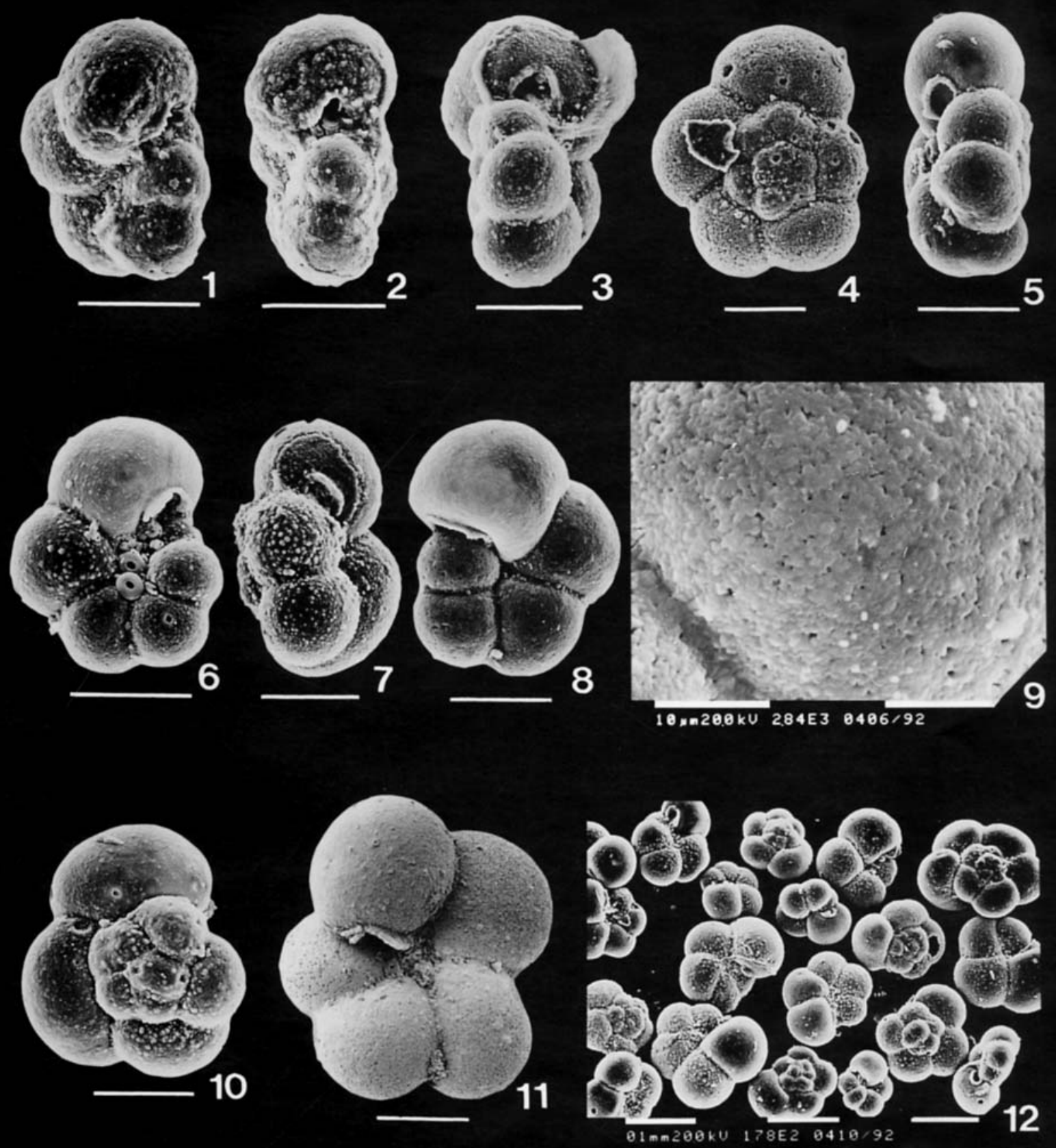


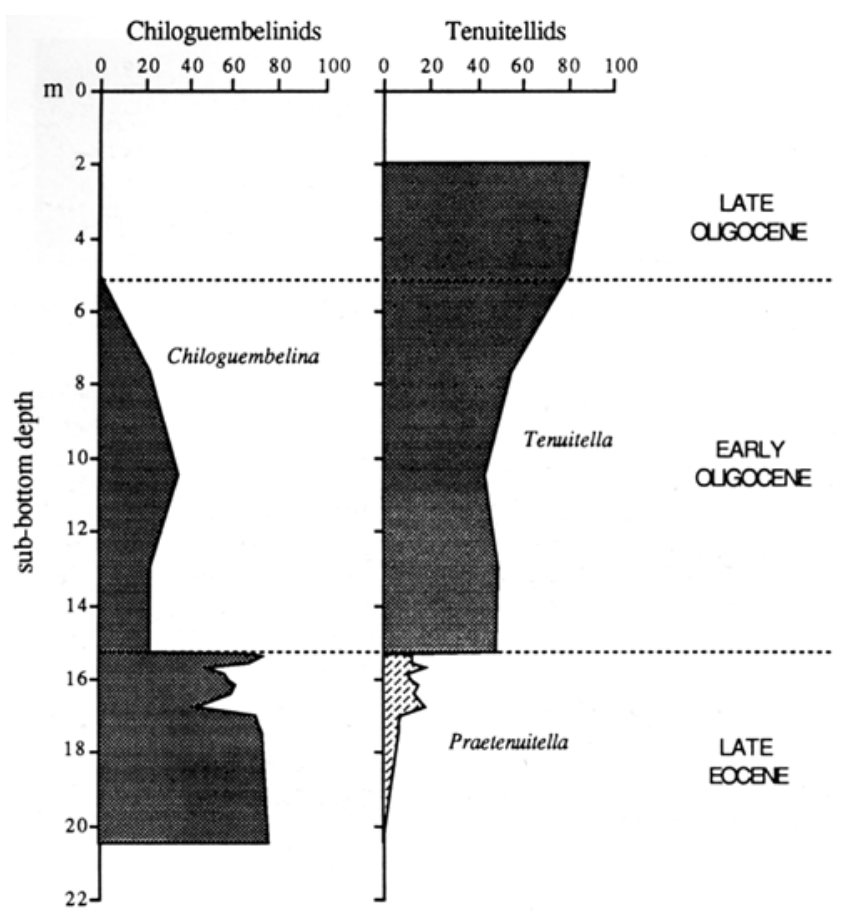

Fig. 4. Abundance of microperforate planktonic foraminifera in the $<150 \mu \mathrm{m}$ fractions from the ODP Hole $749 \mathrm{~B}$ (data from $\mathrm{Li}, 1991$ ). Note that the relative richness of the chiloguembelinids in the late Eocene is coincident with the occurrence of Praetenuitella spp., while typical tenuitellids become predominant in the Oligocene.

The narrow band of high productivity signalled especially by the accumulation of opaline silica, organic carbon and benthic foraminiferal biofacies is neither a localized nor only a neritic phenomenon. The Oamaru Diatomite in New Zealand and the diatomite at Fundo Desbarrancado in Peru are in the same silica window, which in Peru is constrained by the radiolarian Calocyclas bandyca subzone (McGowran, Marty et al., 1989). The silica window thus is trans-Pacific at least, and is sandwiched between a significant warming event early in the late Eocene and the great cooling at the end. We believe that it signifies a brief time of intensified upwelling. Be that as it may, though, the close parallel in time of the silica window and the common and morphologically distinctive $P$. insolita is significant. It is significant too that Praetenuitella appears first at the time of a pronounced spike in abundances of chiloguembelinids at the zone P14/P15 boundary at higher latitudes in the Atlantic Ocean, and that its peak in abundance in the silica window is at the next chiloguembelinid spike in zone P16 (spikes are in Boersma \& Premoli Silva, 1989; Li \& Radford, 1991). The P16 spike in the ocean thus is coeval with the neritic spike in $C$. cubensis shown below the maximum flooding surface of cycle TA4.2 (Fig. 5).

\section{DISCUSSION AND CONCLUSION}

It has been suggested that the evolutionary recovery of planktonic foraminifera after the Cretaceous/Palaeogene boundary event was due to the re-establishment of temperate to warm climate and a new ecosystem in the water column of the global ocean in the earliest Palaeocene. The evidence for that conclusion is rapid colonization and speciation at all latitudes (Boersma \& Premoli Silva, 1991). The most conspicuous evolutionary response is the diversification among the triserial guembelitriids and biserial chiloguembelinids (Boersma \& Premoli Silva, 1989). Although they did not attain the levels of the chiloguembelinids, species of Parvularugoglobigerina commonly constituted $20-50 \%$ of the total fauna. Predominating in mid-latitudes and upwelling regions, the parvularugoglobigerines may have been opportunists seeking nutrientrich waters in the earliest Palaeocene (Boersma \& Premoli Silva, 1991). The small maximum test size and the typical elongate aperture might relate to rapid reproduction and large populations with a range of phenotypes. Eutrophic to highly eutrophic conditions, as depicted by Hallock et al. (1991), are commonly occupied by r-mode opportunists which in this case included the chiloguembelinids and globigerinids. Because opportunistic species can inhabit a broad range of conditions and respond to physical instability they are usually long-lived, in the mode of generalists. Unlike opportunists, however, parvularugoglobigerines occurred only in the earliest Palaeocene for a time span of about half a million years, indicating that they speciated as eutrophic colonizers (Table 1). A record of rare $P$. eugubina in some early Palaeocene sections, such as the Brazos River Section in Texas (Keller, 1989), may indicate a relatively warm, nutrient-poor environment there, unless it had been obscured by hiatuses (Montgomery et al., 1992).

We can use the ecological notions of $\mathrm{r}$ - and $\mathrm{K}$-selection related to the trophic resource continuum (TRC) in the photic zone (Hallock et al., 1991; Boersma \& Premoli Silva, 1991) and relate the fluctuating fortunes of neritic and planktonic communities to the palaeoceanographic events of the Palaeogene at geological, not ecological, time scales. Perhaps reduced oceanic mixing enhances a tendency toward stratification, both oligotrophy and eutrophy at the respective extremes of the TRC and niche specialization, whereas cooling stimulates mixing and promotes opportunism. In broad terms, the diverse communities in K-mode develop in the latest Cretaceous, late Palaeocene-early Eocene, and middle to late Eocene. Following the perturbations at the Cretaceous/Palaeogene, early/middle Eocene and Eocene/Oligocene boundaries respectively, we find survivors or opportunists (see also McGowran, 1991, McGowran et al., 1992).

Populations of Praetenuitella occurred most commonly within the late Eocene which broadly was a time of partial restoration of $\mathrm{K}$-mode communities following the Khirthar transgression (shown on Fig. 6). But the sum of evidence suggests high productivity at the actual times of common Praetenuitella, as discussed above. This may well be due to a pronounced leakage of nutrients into what becomes the silica window at one end of an expanded TRC, still at a time of general warmth (at least at the surface, although bottom waters never warmed greatly again after the global cooling in the early middle Eocene). A cooling spike is shown in 


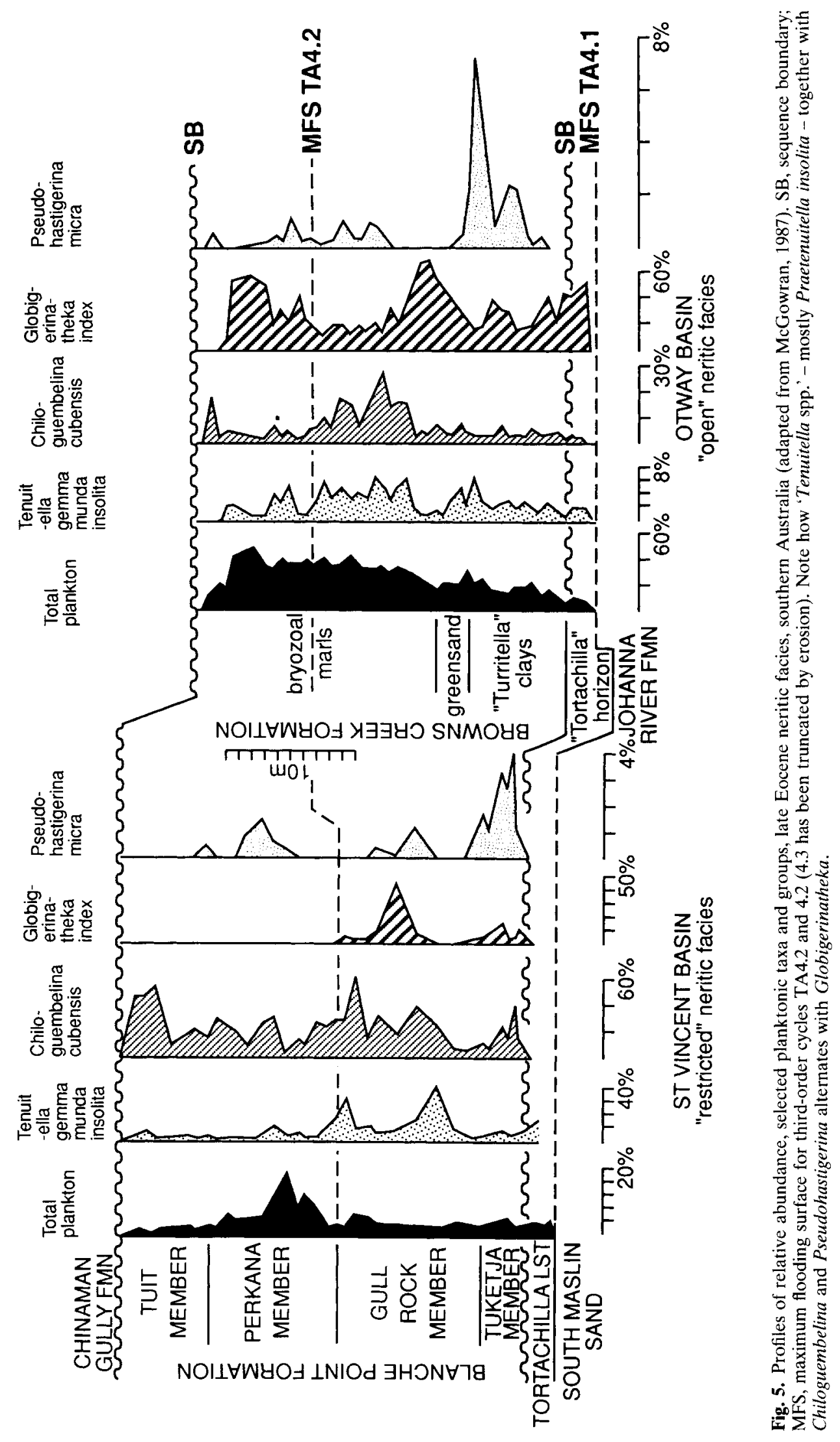




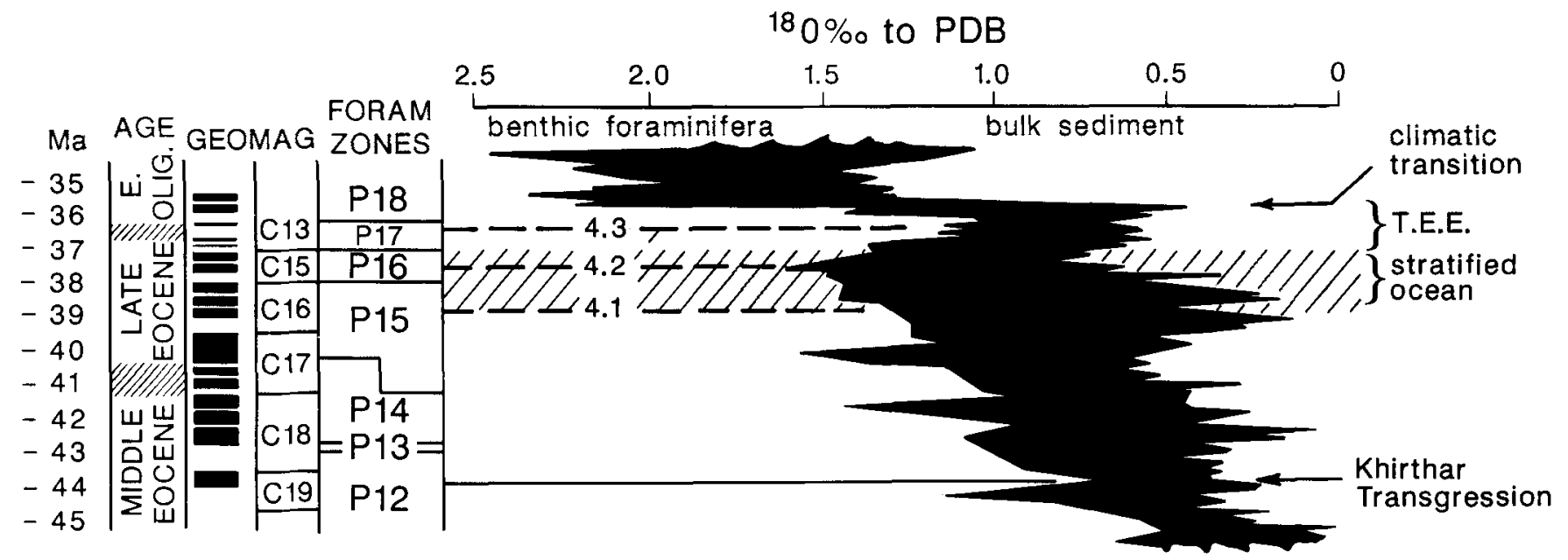

Fig. 6. A Late Eocene scenario, from McGowran (1987, 1989). Time scales, third-order sequences and Shackleton's (1986) isotopic curves, correlated using the Berggren et al. (1985) scales. Wilson Bluff to Aldinga: marine transgressions in southern Australia; Wilson Bluff is but part of the Indo-Pacific Khirthar transgression. It is suggested that the Khirthar transgression and the great cooling in the earliest Oligocene bound the partial restoration of a stratified ocean. Within that time span there is the narrow 'silica window' based on the occurrence of the Fundo Desbarracando, Blanche Point and Oamaru siliceous deposits. Note that the neritic-oceanic silica window spans the neritic record of common 'Tenuitella spp.' (mostly Praetenuitella isolita) in Fig. 5.

Fig. 6 in Zone P16, although it is premature to take correlations at this resolution too seriously in the late Eocene. At present we cannot say whether that event was the stimulus for high productivity or its very opposite, the preceding warming at the Tuketja transgression. The most recent evidence for that comes from the deep sea in the Southern Ocean (Miller, 1992).

The essential point here is not the mechanism but the association of test morphology and facies.

The similar wall in Parvularugoglobigerina and Praetenuitella may reflect similar conditions where slightly corrosive waters are prevailing because, like modern high-latitude forms such as Neogloboquadrina pachyderma and Tenuitellinata uvula (Hemleben et al., 1989), they show a similar pattern in the test morphology, the test became smooth and the porosity decreased. But physiochemical variables were balanced and dissolution was rare. The small, delicate test would otherwise have been dissolved and the variation of various morphotypes eliminated. The growth of calcite crystals on the test wall of $P$. eugubina, according to Olsson et al. (1992), is evidence that the species might be well resistant to dissolution.

The subsequent oceanographic developments in both the Palaeocene and the latest Eocene to early Oligocene may have generated and enhanced competition between the new and surviving species. Warming in the early Palaeocene gave oligotrophic forms, such as the subbotinids and acarininidmorozovellids, opportunities to diversify, whilst forcing Parvularugoglobigerina to extinction in Zone P1. By contrast, the pronounced cooling with steepening thermal gradients close to the Eocene-Oligocene boundary stimulated the replacement of Praetenuitella by the typical tenuitellids (Li, 1991). Unlike their Palaeocene counterparts which left no distinct morphotypes, Praetenuitella spp. were able to change to Tenuitella gemma (Jenkins) and related forms with a pustulate wall and a low aperture in the earliest Oligocene. Some of their descendants, including Tenuitellinata juvenilis (Bolli) and Globigerinita glutinata (Egger) show typical characters of opportunists: little morphological variability and long ranges (Table 1).

In summary, Parvularugoglobigerina and Praetenuitella are unique in possessing a microperforate, smooth test with an elongate aperture. There are variations, particularly in the details of the microperforate wall texture and the trochospiral coiling. Morphotypes of Parvularugoglobigerina exhibit a wall sometimes with pore-mounds and a coiling mode from high to low, while Praetenuitella spp. are constantly smooth and rather low trochospiral. Their respective radiations coincided with two short but significant

\begin{tabular}{|c|c|c|c|}
\hline characters & opportunists & $\begin{array}{c}\text { eutrophic } \\
\text { indices }\end{array}$ & $\begin{array}{l}\text { eutrophic } \\
\text { colonizers }\end{array}$ \\
\hline test size & small-medium & small & small \\
\hline population & small to larger & larger & larger \\
\hline reproduction & rapid & rapid & rapid \\
\hline $\begin{array}{l}\text { morphological } \\
\text { variability }\end{array}$ & low-high & low & high \\
\hline aperture & short/low & long & long \\
\hline surface & pustulate & $\begin{array}{l}\text { smooth- } \\
\text { pustulate }\end{array}$ & pustulate \\
\hline distribution & cosmopolitan & temperate belts & cosmopolitan \\
\hline life strategy & $\begin{array}{c}\text { radiation/little } \\
\text { evolution }\end{array}$ & evolution & radiation \\
\hline life span & longest lived & longer lived & short lived \\
\hline example & $\begin{array}{l}T . \text { juvenilis, } \\
G . g l u t i n a t a \\
\text { (Oligocene- } \\
\text { Recent) }\end{array}$ & $\begin{array}{l}P . \text { insolita } \\
\text { (late } \\
\text { Eocene) }\end{array}$ & $\begin{array}{l}\text { P. eugubina } \\
\text { (earliest } \\
\text { Palaeocene) }\end{array}$ \\
\hline
\end{tabular}

Table 1. Microperforate species differentiated by habitat preferences. 
events in the Cenozoic: the initial return of a normal planktonic ecosystem in the earliest Palaeocene and the climatic fluctuations in the late Eocene. We suggest by morphological pattern analogy, in our ignorance of morphological function, that these forms reflect similar habitat in their similar form and especially in their aperture. The mechanism producing their peculiar morphology may lie in a similar life style in nutrient-rich, oxygen-poor upper waters. This study thus partially supports the suggestion of Banner \& Desai (1988) that all microperforate, non-spinose and non-muricate globigerines preferred such eutrophic conditions where the particle-size of the seston was smallest.

\section{ACKNOWLEDGEMENTS}

We thank Drs W. A. Berggren, C. Hemleben, R. K. Olsson and I. Premoli Silva for discussions. Ms. A Beecroft took some of the SEM photographs. Prof F.T. Banner critically reviewed the manuscript. This work was initiated when the senior author pursued his postgraduate study at the Imperial College London; it would have never been finalized without the support from an Australian Research Council grant to $\mathrm{BMcG}$.

\section{Manuscript received September 1993 Manuscript accepted April 1994}

\section{APPENDIX A. TAXONOMIC NOTES ON PARVULARUGOGLOBIGERINA AND RELATED TAXA}

Apart from the four morphotypes of Parvularugoglobigerina-P. eugubina, $P$. fodina, $P$. perexigua and $P$.alticonusa - several taxa which commonly occur together with or have been referred to as having affinities with the parvularugoglobigerines are discussed here.

alticonusa, Parvularugoglobigerina n. sp. Pl. 2, figs 8-10. This species is proposed for the high-spired parvularugoglobigerines that have been identified as Globigerina minutula by Smit (1982), as Globoconusa conusa by Keller (1988), as Globoconusa minutula by Brinkhuis \& Zachariasse (1988), and as Parvularugoglobigerina morphotype 1 by D'Hondt \& Keller (1991). It is, however, not identical to Globigerina minutula Luterbacher \& Premoli Silva which typically bears a weakly cancellate wall and represents an ancestral form of Subbotina triloculinoides (Boersma \& Premoli Silva, 1983; Premoli Silva, 1990, pers. comm.). Neither is it Globoconusa conusa Khalilov, which is heavily pustulate and has affinity with Globoconusa daubjergensis Brönnimann (Hansen, 1970; Stainforth et al., 1975; Toumarkine \& Luterbacher, 1985). On the other hand, $P$. alticonusa may represent the early and high trochospiral morphotype from which all other species of Parvularugoglobigerina developed.

edita, Globigerina Subbotina, 1953. Brinkhuis \& Zachariasse (1988) assigned some medium-spired microperforate forms to Globigerina edita. Although showing transitional morphology between $P$. alticonusa and $P$. eugubina, the specimens illustrated by these authors may not truly represent Subbotina's species. With a mean size of $250 \mu \mathrm{m}$, the type of $G$. edita is almost twice as large as the specimens assigned to it by these authors. In his work, Blow (1979) did not recognize this species in any small-sized groups but regarded it as a large-sized Eoglobigerina. Blow also described a subspecies $E$. edita praeedita, and both edita and praeedita are distinctly cancellate. Olsson et al. (1992) clarify the matter by confirming that edita is a cancellate Eoglobigerina.

eugubina, Globigerina Luterbacher \& Premoli Silva, 1964. Pl. 1, figs 1-11. This form is characterized by a slightly to strongly flattened test commonly with 5 or more chambers in the final whorl. The test size, commonly $<150 \mu \mathrm{m}$, is variable, as forms as large as $220 \mu \mathrm{m}$ have been measured (Olsson, 1992, pers. comm.). Chambers are subtriangular to oval in strongly compressed tests but become subglobular to globular in tests with increasing spire height. The aperture is constantly elongate, with or without a thin lip. Smit (1982) first clarified the species concept of $P$. eugubina but retained it in the genus Globigerina. The typically mounded to microperforate wall, however, indicates that it is not a Globigerina. The specimens with heavy pustules as drawn by Hofker (1978) might have been mistaken for those with overgrowth of calcite due to dissolution when viewed with light microscopes. The massive calcite crystals are now interpreted by Olsson et al. (1992) to signal its dissolution-resistant capacity. In contrast to these views, Canudo et al. (1991) used longiapertura for those compressed morphotypes.

extensa, Globigerina Blow, 1979. Similar to Parvularugoglobigerina spp. in having a smooth, microperforate wall and an elongate aperture, this taxon may represent a morphotype of this group. Its medium-high trochospiral test and the oblique extraumbilical aperture explicitly show transitional features between those in $P$. alticonusa and $P$. eugubina (see Pls. 1-2). It is thus considered to be an intermediate form between the latter two.

fodina, Eoglobigerina Blow, 1979. Pl. 2, figs 6, 7. This is a rare but typically smooth-walled morphotype of Parvularugoglobigerina. Unlike $P$. eugubina, $P$. fodina has a medium-high trochospire with an aperture which is almost circular on the umbilical side. Chambers are inflated or globular, with 3-4 constituting the final whorl. Bordered with a thin lip, its circular aperture represents an extreme variation to the Globigerina bulloides-type morphology. As Globobastica Blow possesses a densily pustulate wall and is probably a junior synonym of Globoconusa Khalilov ( $\mathrm{Li}$, 1991), it should not embrace this smooth-walled species, as suggested by Canudo et al. (1991).

fringa, Globigerina Subbotina, 1953. Stainforth et al. (1975), Smit (1982) and Berggren (1992) all considered Globigerina fringa to be densely perforate to weakly cancellate, so that $G$. fringa should be considered as typical Eoglobigerina and probably synonymous with $E$. eobulloides, as in Stainforth et al. (1975) and Toumarkine \& Luterbacher (1985). Material from Russia did show $G$. fringa to be cancellate (Olsson, 1992, pers. comm.). For this reason, any proposals that $G$. fringa might be a parvularugoglobigerine could not be upheld, and all the previous records of $P$. fringa by authors should be 
considered to represent those of the new species $P$. perexigua.

hariana, Postrugoglobigerina Salaj, 1986 (fide Loeblich \& Tappan, 1988). This is a trochospiral form with pore-mounds found in the lowermost Palaeocene of Tunisia. The overall morphology overlaps with that observed in some Parvularugoglobigerina eugubina and $P$. fringa. It appears to us that the type specimens of this taxon probably represent an immediate descendant from Guembelitria.

hillebrandti, Globigerina Orue-Etxebarria, 1985. The medioperforate to weakly cancellate wall in this taxon is similar, if not identical, to that in Globigerina fringa of Stainforth et al. (1975) and Smit (1982), although its chamber enlargement in the final whorl is slow. Whether $G$. hillebrandti and $G$. fringa of authors represents a single species is not clear, but the cancellate wall suggests that $G$. hillebrandti belongs to neither Globigerina nor Parvularugoglobigerina, but to Eoglobigerina.

longiapertura, Globorotalia (Turborotalia) Blow, 1979. This work follows the conventional view that this species is a junior synonym of $P$. eugubina (Smit, 1982; Li \& Radford, 1991; Olsson et al., 1992). By contrast, Canudo et al. (1991) recognized this species for forms with a compressed, multichambered test and a narrow elongate aperture, some extreme variants of $P$. eugubina (above). Further work is necessary to resolve this.

minutula, Globigerina Luterbacher \& Premoli Silva, 1964. According to Krasheninnikov \& Hoskins (1973) and Boersma \& Premoli Silva (1983), this is a weakly cancellate form having affinity with Subbotina triloculinoides, although Stainforth et al. (1975) regarded it as a junior synonym of Globigerina fringa. In contrast, Smit (1982) illustrated a smooth, microperforate form as representing this taxon. Smit's species concept was followed by Brinkhuis \& Zachariasse (1988) but as Globoconusa minutula. This study, however, identifies all high trochospiral forms with a smooth and microperforate wall as $P$. alticonusa (see below), for the same reason as indicated by Premoli Silva (1990, pers. comm.), that typical minutula represents an early Subbotina because it bears a weakly cancellate wall.

perexigua, Parvularugoglobigerina n. sp. Pl. 2, figs 1-5. This is a tiny form (about $80 \mu \mathrm{m}$ ) with only 4 chambers in the last whorl but possessing a microperforate, smooth wall as in the majority of $P$. eugubina. Otherwise it is similar to equally small but weakly cancellate Eoglobigerina fringa (Subbotina). As E. fringa is not a parvularugoglobigerine, this species is proposed to include those described previously under $P$. fringa in Brinkuis \& Zachariasse (1988) and $\mathrm{Li} \&$ Radford (1991), among others. The concept of Parvularugoglobigerina morphotype 2 of D'Hondt \& Keller (1991) falls within this new species. See systematic description below.

\section{SYSTEMATICS}

Genus Parvalarugoglobigerina Hofker, 1978

(Type species: Globigerina eugubina Luterbacher \& Premoli Silva, 1964)

Parvularugoglobigerina alticonusa sp. nov.

(Pl. 2, figs 8-10)
Holotype. DSDP Hole 152, Caribbean. Sample i52-10-1, $140-143 \mathrm{~cm}, P$. eugubina Zone. Pl. 2, fig. 9.

Description. Test small, high trochospiral, chambers subglobular, four in the final whorl, wall smooth to weakly pustulate, early part sometimes with pore mounds, aperture elongate, extending obliquely from the base of last chamber near the umbilicus to the apertural face, with a distinct lip.

Remarks. This species is proposed to include forms described by authors as Globigerina minutula (Luterbacher \& Premoli Silva) which, however, is a medium-spired, cancellate form. See above for notes on these two species.

\section{Parvularugoglobigerina perexigua sp. nov.} (Pl. 2, figs 1-5)

Holotype. DSDP Hole 152, Caribbean. Sample 152-10-1, 140-143 cm, P. eugubina Zone. Pl. 2, figs 1-3.

Description. Test small, about $80 \mu \mathrm{m}$, low trochospiral, chamber subglobular, increasing rapidly, four chambers in the final whorl, wall smooth to weakly pustulate, rarely with pore mounds, aperture elongate, extraumbilicalperipheral, or extending to the upper part of the apertural face, with or without a thin lip.

Remarks. This species is proposed to include forms which have been widely misidentified as Globigerina fringa by several workers. Studies of Russian material by the Palaeogene Planktonic Foraminiferal Working Group, however, indicate that $G$. fringa belongs to the cancellate group (Olsson, 1992, pers. comm.) and should be considered a species of Eoglobigerina (Berggren, 1992). See above for notes on these two species.

\section{APPENDIX B. TAXONOMIC NOTES ON PRAETENUITELLA spp.}

impariapertura, Praetenuitella $\mathrm{Li}, 1987$. Although the apertures in both impariapertura and insolita (below) are similarly high and peripheral to extraumbilical, this taxon can be distinguished from the latter by its rather high elliptical test outline, concave dorsal side and a wide umbilicus. It appears to be a low latitude representive of that genus.

insolita, Globorotalia Jenkins, 1966. Pl. 3, figs 1-12; Pl. 4, figs $7-9$. This species is characterized by a smooth wall and a highly arched aperture. It differs from $P$. impariapertura by its almost circular test outline, a convex dorsal side and a narrow umbilicus. It has been recorded in the late Eocene of New Zealand (Jenkins, 1966), equatorial Pacific (Jenkins \& Orr, 1972, DSDP Hole 77), East Pacific (Quilty, 1976, DSDP Hole 321), Tasman Sea (Jenkins \& Srinivasan, 1985, DSDP Hole 592), southern Australia (Lindsay, 1985; McGowran, 1987), Japan (Kaiho, 1984), Washington State (Jenkins \& Srinivasan, 1985), southern Atlantic Ocean (Nocchi et al., 1991, ODP Hole 703), and southern Indian Ocean (Li et al., 1992).

patefecta, Praetenuitella $\mathrm{Li}, 1987$. Pl. 4, figs 1-4. Similar to $P$. impariapertura, this taxon has a high elliptical test outline with more than 5 chambers in the final whorl, a flat dorsal side and a wide umbilicus, but can be identified by its more distinct trochospiral coiling with a flat spiral side and an 
aperture being peripheral-extraumbilical-umbilical, rather than only peripheral-(short) extraumbilical.

praegemma, Praetenuitella Li, 1987. Pl. 4, figs 10, 11. This form is recognized by its four- or five-chambered, biconvex test and an extraumbilical aperture. It differs from the immediate early Oligocene descendant Tenuitella gemma (Jenkins) in having a smooth to weakly pustulate (rather than heavily pustulate) microperforate wall.

\section{REFERENCES}

Banner, F. T. 1989. The nature of Globanomalina Haque. Journal Foraminiferal Research, 19: 171-179.

Banner, F. T. \& Desai, D. 1988. A review and revision of the Jurassic-Early Cretacoeus Globigerinina, with especial reference to the Aptian assemblages of Speeton (North Yorkshire, England). Journal of Micropalaeontology, 7: 143-185.

Banner, F. T., Copestake, P. \& White, M. R 1993. BarremianAptian Praehedbergellidae of the North Sea area: a reconnaissance. Bulletin of the Natural History Museum (Geology), 49: $1-30$.

Berggren, W. A. 1992. Paleogene planktonic foraminifer magnetobiostratigraphy of the southern Keuguelen Plateau (Sites 747-749). In Wise, S. W. Jr., Schlich, R., et al., Proceedings of $O D P$, Scientific Results, College Station, TX (Ocean Drilling Program), 120: 551-568.

Berggren, W. A. \& Miller, K. G. 1988. Paleogene tropical planktonic foraminiferal biostratigraphy and magnetobiochronology. Micropaleontology, 34: 362-380.

Berggren, W. A., Kent, D. V. \& Flynn, J. J. 1985. Paleogene geochronology and chronostratigraphy. In Snelling, N. J. (Ed.), The Chronology of the Geological Record. Geological Society of London Memoir, 10: 141-195.

Blow, W. H. 1979. The Cainozoic Globigerinida. E. J. Brill, Leiden, 3 vols, 1413pp.

Boersma, A. \& Premoli Silva, I. 1983. Paleocene planktonic foraminiferal biogeography and the paleoceanography of the Atlantic Ocean. Micropaleontology, 29: 355-381.

Boersma, A. \& Premoli Silva, I. 1988. Boundary conditions of Atlantic oxygen minimum zones. Rivista italiana di paleontolgria e stratigrafia, 93: 479-506.

Boersma, A. \& Premoli Silva, I. 1989. Atlantic Paleogene biserial heterohelicid foraminifera and oxygen minimum. Paleoceanography, 4: 271-286.

Boersma, A. \& Premoli Silva, I. 1991. Distribution of Paleogene planktonic foraminifera - analogies with the Recent? Palaeogeography, Palaeoclimatology, Palaeoecology, 83: 29-47.

Brinkhuis, H. \& Zachariasse, W. J. 1988. Dinoflagellate cysts, sea level changes and planktonic foraminifers across the CretaceousTertiary boundary at El Haria, northwest Tunisia. Marine Micropaleontology, 13: 153-191.

Canudo, J. I., Keller, G. \& Molina, E. 1991. Cretaceous/Tertiary boundary extinction pattern and faunal turnover at Agost and Caravaca, S.E. Spain. Mar. Micropaleont., 17: 319-341.

D'Hondt, S. \& Keller, G. 1991. Some patterns of planktic foraminiferal assemblages turnover at the Cretaceous-Tertiary boundary. Mar. Micropaleont., 17: 1-42.

Gerstel, J., Thunell, R. C., Zachos, J. C. \& Arthur, M. A. 1986. The Cretaceous/Tertiary event in the North Pacific: planktonic foraminiferal results from Deep Sea Drilling Project Site 577, Shatsky Rise. Paleoceanography, 1: 97-117.

Hallock, P., Premoli Silva, I. \& Boersma, A. 1991. Similarities between planktonic and larger foraminiferal evolutionary trends through Paleogene paleoceanographic changes. Palaeogeogr., Palaeoclimatol., Palaeoecol., 83: 49-64.

Hansen, H. J. 1970. Biometric studies on the stratigraphic evolution of Globoconusa daubjergensis (Brönnimann) from the Danian of Denmark. Meddelelser fra Dansk Geologisk forening, 19: 341-360.

Haq, B. U. \& Van Eysinga, F. W. B. 1987. Geological Time Scale. 4th edition, Elsevier, New York.
Hemleben, C., Spindler, M. \& Anderson, O. R. 1989. Modern Planktonic Foraminifera. Springer-Verlag, New York, 363pp.

Hemleben, C., Mühlen, D., Olsson, R. K. \& Berggren, W. A. 1991. Surface texture and the first occurrence of spines in planktonic foraminifera from the early Tertiary. Geologisches Jalirbuch, A128: $117-146$.

Herm, D., Hillebrandt, A. v. \& Perch-Nielsen, K. 1981. Die Kreide/Tertiar-Grenze im Lattengebirge (Nordliche Kalkalpen) in mikropalaontologischer Sicht. Geologica Bavarica, 82: 319-344.

Hofker, J. 1978. Analysis of a large succession of samples through the upper Maastrichtian and the lower Tertiary of drill hole 47.2, Shatsky Rise, Pacific, Deep Sea Drilling Project. Journal of Foraminferal Research, 8: 46-75.

Jenkins, D. G. 1966. Planktor ic foraminiferal zones and new taxa from the Danian to lower Miocene of New Zealand. New Zealand Journal of Geology and Geophysics, 8: 1088-1126.

Jenkins, D. G. \& Orr, W. N. 1972. Planktonic foraminiferal biostratigraphy of the east equatorial Pacific - DSDP Leg 9. In Hays J. D., et al., Initial Reports of the DSDP, U.S. Government Printing Office, Washington DC, 9: 1059-1193.

Jenkins, D. G. \& Srinivasan, M. S. 1985. Cenozoic planktonic foraminifers from the equatorial to the sub-Antarctic of the southwest Pacific. In Kennett, J. P., von der Borch, C. C., et al., Initial Reports of the DSDP, U.S. Government Printing Office, Washington DC, 90: 795-834.

Kaiho, K. 1984. Paleogene foraminifera from Hokkaido, Japan (part 2). Tohoku University, Scientific Reports, 2nd series (Geology), 55: 1-74.

Keller, G. 1988. Extinction, survivorship and evolution of planktic foraminifera across the Cretaceous/Tertiary boundary at El Kef, Tunisia. Marine Micropaleontology, 13: 239-263.

Keller, G. 1989. Extended period of extinctions across the Cretaceous/Tertiary boundary in planktonic foraminifera of continental-shelf sections: implications for impact and volcanism theories. Geological Society of America Bulletin, 101: 1408-1419.

Krasheninnikov, V. A. \& Hoskins, R. H. 1973. Late Cretaceous, Paleogene and Neogene planktonic foraminifera. In Heezen, B. C., MacGregor, I. D. et al., Initial Reports of the DSDP, U.S. Government Printing Office, Washington DC, 20: 105-203.

$\mathrm{Li}$, Qianyu 1987. Origin, phylogenetic development and systematic taxonomy of the Tenuitella plexus (Globigerinitidae, Globigerinina). Journal of Foraminiferal Research, 17: 298-320.

Li, Qianyu 1991. Evolution and Distribution of Cenozoic Microperforate Planktonic Foraminifera. University of London (Unpublished PhD Thesis), $243 \mathrm{p}$.

Li, Qianyu \& Radford, S. S. 1991. Evolution and biogeography of Paleogene microperforate planktonic foraminifera. Palaeogeography, Palaeoclimatology, Palaeoecology, 83: 87-115.

Li, Qianyu, Radford, R. R. \& Banner, F. T. 1992. Distribution of microperforate tenuitellid planktonic foraminifers in Holes $747 \mathrm{~A}$ and 749B, Kerguelen Plateau. In Wise, S. W. Jr., Schlich, R., et al., Proceedings ODP, Scient. Results, College Station, TX (Ocean Drilling Program), 120: 569-594.

Lindsay, J. M. 1985. Aspects of South Australia Tertiary foraminiferal biostratigraphy, with emphasis on studies of Massilina and Subbotina. South Australian Department of Mines Energy, Special Publication, 5: 187-231.

Loeblich, A. R. Jr. \& Tappan, H. 1988. Foraminiferal Genera and their Classification. Van Nostrand, New York, 2 vols.

Luterbacher, H. \& Premoli Silva, I. 1964. Biostratigraphia del limite Cretaceo-Terziario nell'Appennino centrale. Rivista italiana di paltontologia e stratigrafia, 70: 67-128.

McGowran, B. 1987. Late Eocene perturbations: foraminiferal biofacies and evolutionary overturn, southern Australia. Paleoceanography, 2: 715-727.

McGowran, B. 1989. The later Eocene transgressions in southern Australia. Alcheringa, 13: 45-68.

McGowran, B., Marty, R. et al., 1989. Comment and reply on 'Late Eocene diatomite from the Peruvian coastal desert, coastal upwelling in the eastern Pacific, and Pacific circulation before the terminal Eocene event'. Geology, 17: 957-959. 
McGowran, B. 1990. Fifty million years ago. American Scientist, 78: 30-39.

McGowran, B. 1991. Evolution and environment in the early Palaeogene. Memoir Geological Society of India, 20: 21-53.

McGowran, B. 1992. Eocene patterns and processes. Encyclopedia of Earth System Science. Academic Press, 2: 163-172.

McGowran, B. \& Beecroft, A. 1986. Foraminiferal biofacies in a silica-rich neritic sediment, Late Eocene, South Australia. Palaeogeograpy, Palaeoclimatology, Palaeoecology, 52: 321-345.

McGowran, B., Moss, G. \& Beecroft, A. 1992. Late Eocene and early Oligocene in Southern Australia: local neritic signals of global oceanic changes. In Prothero, D. R. \& Berggren, W. A. (Eds), Eocene-Oligocene Climatic and Biotic Evolution. Princeton University Press, 178-201.

Miller, K.G. 1992. Middle Eocene to Oligocene stable isotopes, climate, and deep-water history: the Terminal Eocene Event? In: Prothero, D. R. \& Berggren, W. A. (Eds), Eocene-Oligocene Climatic and Biotic Evolution. Princeton University Press, 160-177.

Montgomery, H., Pessagno, E., Soegaard, K., Smith, C., Munoz, I. \& Pessagno, J. 1992. Misconceptions concerning the Cretaceous/Tertiary boundary at the Brazos River, Falls County, Texas. Earth Planetary Science Letters, 109: 593-600.

Nocchi, M., Amici, E. \& Premoli Silva, I. 1991. Planktonic foraminifer biostratigraphy and paleoenvironmental interpretation of Paleogene faunas from subantarctic transect, ODP Leg 114. In Ciesielski, P. F., Kristoffersen, Y., et al., Proceedings of $O D P$, Scientific Results, College Station, TX (Ocean Drilling Program), 114: 233-279.

Olsson, K. R., Hemleben, C., Berggren, W. A. \& Liu, C. 1992. Wall texture classification of planktonic foraminifera genera in the lower Danian. Journal Foraminiferal Research., 22: 195-213.

Orue-Etxebarria, X. 1985. Descripcion de Globigerina hillebrandti n. sp. en el limite Cretacico/Terciario de la seccion de Sopelana (Pais Vasco) Evolucion de los primeros foraminiferos planctoni- cos al comienzo del Terciario. Newsletters on Stratigraphy Berlin, 15: $71-80$.

Premoli Silva, I. 1977. The earliest Tertiary Globigerina eugubina zone: paleontological significance and geographical distribution. Memoria, Sequndo Congresso Latinamericano de Geologia (Caracas, Venezuela, 1973), III, Special Publications, 7: $1541-1555$.

Quilty, P. G. 1976. Planktonic foraminifera, DSDP Leg 34. In Yeats. R. S., Hart, S. R. et al., Initial Reports of the DSDP, U.S. Government Printing Office, Washington, 34: 629-703.

Shackleton, N. J. 1986. Paleogene stable isotope events. Palaeogeography, Palaeoclimatology, Palaeoecology, 57: 91-102.

Smit, J. 1982. Extinction and evolution of planktonic foraminifera after a major impact at the Cretaceous/Tertiary boundary. In Silver, L. T. \& Schulz, P. H. (Eds), Geological Implications of Impacts of Large Asteroids and Comets on the Earth. Geological Society America Special Paper, 190: 329-352.

Stainforth, R. M., Lamb, J. L., Luterbacher, H., Beard, J. \& Jeffords, R. M. 1975. Cenozoic Planktonic Foraminiferal Zonation and Characteristics of Index Forms. University of Kansas Paleontology Contribution, 62: 425pp.

Stott, L. D. \& Kennett, J. P. 1990. Antarctic Paleogene planktonic foraminifer biostratigraphy: ODP Leg 113 Sites 689 and 690. In Barker, P. F., Kennett, J. P., et al., Proceedings $O D P$, Scientific Results, College Station, TX (Ocean Drilling Program), 113: $549-567$.

Subbotina, N. N. 1953. Globigerinidi, Hantkeninidi i Globorotaliidi. Iskopaemie Foraminiferi SSSR. Trudi, VNIGRI, 76: 1-296 (English translation: Fossil Foraminifera of the USSR, by E. Lees, 1971, Collets Ltd., London).

Toumarkine, M. \& Luterbacher, H. 1985. Paleocene and Eocene planktic foraminifera. In Bolli, H. M., Saunders, J. B. \& Perch-Nielsen, K. (Eds), Plankton Stratigraphy. Cambridge University Press, Cambridge, 87-154. 